\title{
IMPLEMENTASI KESETARAAN DAN KEADILAN GENDER DALAM KELUARGA
}

\section{Rustina}

\begin{abstract}
Implementation of gender equality and justice in the family is the functioning of a good family order as an absolute prerequisite for the survival of a new generation of values and norms in accordance with the expectations of society, the realization of mutual understanding of the role of each in the family is characterized by the absence of discrimination between women and men, and thus they have access, opportunity to participate, and control over development and equitable and fair benefits in all sectors of development.
\end{abstract}

Keyword: Implementation of gender equality, justice, in the family

\section{PENDAHULUAN}

Kesetaraan dan Keadilan Gender (KKG) sudah menjadi isu yang sangat penting dan sudah menjadi komitmen bangsa-bangsa di dunia termasuk Indonesia sehingga seluruh negara menjadi terikat dan harus melaksanakan komitmen tersebut. Upaya mewujudkan Kesetaraan dan Keadilan Gender (KKG), di Indonesia dituangkan dalam kebijakan nasional sebagaimana ditetapkan dalam Garis-Garis Besar Haluan Negara (GBHN) 1999, UU No. 25 th. 2000 tentang Program Pembangunan Nasional-PROPENAS 2000-2004, dan dipertegas dalam Instruksi Presiden No. 9 tahun 2000 tentang Pengarusutamaan Gender (PUG) 
dalam Pembangunan nasional, sebagai salah satu strategi untuk mewujudkan keadilan dan kesetaraan gender. ${ }^{1}$

Disamping itu pengarus utamaan gender juga merupakan salah satu dari empat key cross cutting issues dalam Propenas. Pelaksanaan PUG diisntruksikan kepada seluruh departemen maupun lembaga pemerintah dan non departemen di pemerintah nasional, propinsi maupun di kabupaten/kota, untuk melakukan penyusunan program dalam perencanaan, pelaksanaan, pemantauan dan evaluasi dengan mempertimbangkan permasalahan kebutuhan, aspirasi perempuan pada pembangunan dalam kebijakan, program/proyek dan kegiatan.

Disadari bahwa keberhasilan pembangunan nasional di Indonesia baik yang dilaksanakan oleh pemerintah, swasta maupun masyarakat sangat tergantung dari peran serta laki-laki dan perempuan sebagai pelaku dan pemanfaat hasil pembangunan. Pada pelaksanaannya sampai saat ini peran serta kaum perempuan belum dioptimalkan. Oleh karena itu program pemberdayaan perempuan telah menjadi agenda bangsa dan memerlukan dukungan semua pihak

Ketertinggalan perempuan mencerminkan masih adanya ketidakadilan dan ketidak setaraan antara laki-laki dan perempuan di Indonesia, hal ini dapat terlihat dari gambaran kondisi perempuan di Indonesia. Sesungguhnya perbedaan gender dengan pemilahan sifat, peran, dan posisi tidak menjadi masalah sepanjang tidak melahirkan ketidakadilan. Namun pada kenyataannya perbedaan gender telah melahirkan berbagai ketidak adilan, bukan saja bagi kaum perempuan, tetapi juga bagi kaum laki-laki.

Berbagai pembedaan peran, fungsi, tugas dan tanggung jawab serta kedudukan antara laki-laki dan perempuan baik secara

${ }^{1}$ BPS, United Nations Developmen Fund for Women. Gender Statistics and Indicators (2000) 11. 
langsung maupun tidak langsung, dan dampak suatu peraturan perundang-undangan maupun kebijakan telah menimbulkan berbagai ketidakadilan karena telah berakar dalam adat, norma ataupun struktur masyarakat. Gender masih diartikan oleh masyarakat sebagai perbedaan jenis kelamin. Masyarakat belum memahami bahwa gender adalah suatu konstruksi budaya tentang peran fungsi dan tanggung jawab sosial antara laki-laki dan perempuan. Kondisi demikian mengakibatkan kesenjangan peran sosial dan tanggung jawab sehingga terjadi diskriminasi, terhadap laki-laki dan perempuan. Hanya saja bila dibandingkan, diskriminasi terhadap perempuan kurang menguntungkan dibandingkan laki-laki.

Faqih dalam Achmad M. menyatakan, ketidak adilan gender adalah suatu sistem dan struktur yang menempatkan laki-laki maupun perempuan sebagai korban dari sistem. Selanjutnya Achmad M. menyatakan, ketidak adilan gender termanifestasikan dalam berbagai bentuk ketidakadilan, terutama pada perempuan; misalnya marginalisasi, subordinasi, stereotipe/pelabelan negatif sekaligus perlakuan diskriminatif. Maka manisfestasi ketidakadilan gender tersebut masing-masing tidak bisa dipisah-pisahkan, saling terkait dan berpengaruh secara dialektis ${ }^{2}$

Bedasarkan pandangan di atas maka berupa kekerasan terhadap perempuan dalam bentuk beban kerja lebih banyak jika di bandingkan dengan kaum laki-laki. Kenyataannya dalam beberapa aspek pembangunan, perempuan kurang dapat berperan aktif. Hal ini disebabkan karena kondisi dan posisi yang kurang menguntungkan dibanding laki-laki. Seperti peluang dan kesempatan yang terbatas dalam mengakses dan mengontrol sumberdaya pembangunan, sistem upah yang merugikan, tingkat kesehatan dan pendidikan yang

${ }^{2}$ Achmad Muthali'in, Bias Gender dalam Pendidikan, (Surakarta, Muhammadiyah University Press, 2001). 33 
rendah, sehingga manfaat pembangunan kurang diterima kaum perempuan.

Berbagai upaya pembangunan nasional yang selama ini diarahkan untuk meningkatkan kualitas sumber daya manusia, baik perempuan maupun laki-laki, ternyata belum dapat memberikan manfaat yang setara bagi perempuan dan laki-laki. Bahkan belum cukup efektif memperkecil kesenjangan yang ada. Hal ini menunjukkan bahwa hak-hak perempuan memperoleh manfaat secara optimal belum terpenuhi sehingga pembangunan nasional belum mencapai hasil yang optimal, karena masih belum memanfaatkan kapasitas sumber daya manusia secara penuh.

Faktor penyebab kesenjangan gender yaitu Tata nilai sosial budaya masyarakat, umumnya lebih mengutamakan laki-laki daripada perempuan (ideology patriarki); Peraturan perundangundangan masih berpihak pada salah satu jenis kelamin dengan kata lain belum mencerminkan kesetaraan gender; Penafsiran ajaran agama yang kurang komprehensif atau cenderung tekstual kurang kontekstual, cenderung dipahami parsial kurang kholistik; Kemampuan, kemauan dan kesiapan perempuan sendiri untuk merubah keadaan secara konsisten dan konsekwen; Rendahnya pemahaman para pengambil keputusan di eksekutif, yudikatif, legislatif terhadap arti, tujuan, dan arah pembangunan yang responsif gender.

Kesenjangan pada kondisi dan posisi laki-laki dan perempuan menyebabkan perempuan belum dapat menjadi mitra kerja aktif laki-laki dalam mengatasi masalah-masalah sosial, ekonomi dan politik yang diarahkan pada pemerataan pembangunan. Selain itu rendahnya kualitas perempuan turut mempengaruhi kualitas generasi penerusnya, mengingat mereka mempunyai peran reproduksi yang sangat berperan dalam mengembangkan sumber daya manusia masa depan bangsa. 


\section{PEMBAHASAN}

\section{Pengertian Kesetaraan dan Keadilan gender}

Kesetaraan gender berarti kesamaan kondisi bagi laki-laki dan perempuan untuk memperoleh kesempatan serta hak-haknya sebagai manusia, agar mampu berperan dan berpartisipasi dalam kegiatan politik, hukum, ekonomi, sosial budaya, pendidikan dan pertahanan dan keamanan nasional (hankamnas), serta kesamaan dalam menikmati hasil pembangunan tersebut. Kesetaraan gender juga meliputi penghapusan diskriminasi dan ketidak adilan struktural, baik terhadap laki-laki maupun perempuan.

Keadilan gender adalah suatu proses dan perlakuan adil terhadap perempuan dan laki-laki. Dengan keadilan gender berarti tidak ada pembakuan peran, beban ganda, subordinasi, marginalisasi dan kekerasan terhadap perempuan maupun laki-laki.

Terwujudnya kesetaran dan keadilan gender ditandai dengan tidak adanya diskriminasi antara perempuan dan laki-laki, dan dengan demikian mereka memiliki akses, kesempatan berpartisipasi, dan kontrol atas pembangunan serta memperoleh manfaat yang setara dan adil dari pembangunan.

Memilii akses dan partisipasi berarti memiliki peluang atau kesempatan untuk menggunakan sumber daya dan memiliki wewenang untuk mengambil keputusan terhadap cara penggunaan dan hasil sumber daya tersebut. Memiliki kontrol berarti memiliki kewenangan penuh untuk mengambil keputusan atas penggunaan dan hasil sumber daya. Sehingga memperoleh manfaat yang sama dari pembangunan.

\section{Konsep Gender dan Seks}

Gender adalah perbedaan dan fungsi peran sosial yang dikonstruksikan oleh masyarakat, serta tanggung jawab laki-laki dan perempuan, sehingga gender belum tentu sama di tempat yang berbeda, dan dapat berubah dari waktu ke waktu. Berbeda dengan 
jenis kelamin yang terdiri dari perempuan dan laki-laki yang telah ditentukan oleh Tuhan serta tidak dapat ditukar atau diubah. Ketentuan ini berlaku sejak dahulu kala, sekarang dan berlaku selamanya.

Perlu ditegaskan kembali bahwa Gender bukanlah kodrat ataupun ketentuan Tuhan. Oleh karena itu gender berkaitan dengan proses keyakinan bagaimana seharusnya laki-laki dan perempuan berperan dan bertindak sesuai dengan tata nilai yang terstruktur, ketentuan sosial dan budaya ditempat mereka berada. Jadi sangat ironis apabila Gender masih diartikan oleh masyarakat sebagai perbedaan jenis kelamin.

Masyarakat belum memahami bahwa gender adalah suatu konstruksi budaya tentang peran fungsi dan tanggung jawab sosial antara laki-laki dan perempuan. Kondisi demikian mengakibatkan kesenjangan peran sosial dan tanggung jawab sehingga terjadi diskriminasi, terhadap laki-laki dan perempuan. Hanya saja bila dibandingkan, diskriminasi terhadap perempuan kurang menguntungkan dibandingkan laki-laki.

Faktor utama penyebab kesenjangan gender adalah tata nilai sosial budaya masyarakat, pada umumnya lebih mengutamakan laki-laki dari pada perempuan (ideology patriarki). Disamping itu, penafsiran ajaran agama yang kurang komprehensif atau cenderung tekstual kurang kontekstual, cenderung dipahami parsial kurang holistik. Sementara itu, kemampuan, kemauan dan kesiapan perempuan sendiri untuk merubah keadaan tidak secara konsisten dan konsekwen. Dalam kehidupan politik, pemahaman para pengambil keputusan di eksekutif, yudikatif, legislatif terhadap arti, tujuan, dan arah pembangunan dirasakan kurang responsif gender.

Kesetaraan dan Keadilan Gender sudah menjadi isu yang sangat penting dan sudah menjadi komitmen bangsa-bangsa di dunia termasuk Indonesia sehingga seluruh negara menjadi terikat dan harus melaksanakan komitmen tersebut. Kita semua menyadari 
bahwa keberhasilan pembangunan nasional di Indonesia baik yang dilaksanakan oleh pemerintah, swasta maupun masyarakat sangat tergantung dari peran serta laki-laki dan perempuan sebagai pelaku dan pemanfaat hasil pembangunan.

Gender adalah perbedaan dan fungsi peran sosial yang dikonstruksikan oleh masyarakat, serta tanggung jawab laki-laki dan perempuan Sehingga gender belum tentu sama di tempat yang berbeda, dan dapat berubah dari waktu ke waktu.

Seks/kodrat adalah jenis kelamin yang terdiri dari perempuan dan laki-laki yang telah ditentukan oleh Tuhan. Oleh karena itu tidak dapat ditukar atau diubah. Ketentuan ini berlaku sejak dahulu kala, sekarang dan berlaku selamanya.

Gender bukanlah kodrat ataupun ketentuan Tuhan. Oleh karena itu gender berkaitan dengan proses keyakinan bagaimana seharusnya laki-laki dan perempuan berperan dan bertindak sesuai dengan tata nilai yang terstruktur, ketentuan sosial dan budaya ditempat mereka berada. Dengan demikian gender dapat dikatakan pembedaan peran, fungsi, tanggung jawab antara perempuan dan laki-laki yang dibentuk/dikonstruksi oleh sosial budaya dan dapat berubah sesuai perkembangan zaman.

Perbedaan gender dan jenis kelamin (seks) adalah Gender: dapat berubah, dapat dipertukarkan, tergantung waktu, budaya setempat, bukan merupakan kodrat Tuhan, melainkan buatan manusia.

Lain halnya dengan seks, seks tidak dapat berubah, tidak dapat dipertukarkan, berlaku sepanjang masa, berlaku dimana saja, di belahan dunia manapun, dan merupakan kodrat atau ciptaan Tuhan.

\section{Bentuk-bentuk Ketidakadilan Akibat Diskriminasi Gender}

a. Marginalisasi perempuan sebagai salah satu bentuk ketidakadilan gender 
Proses marginalisasi (peminggiran/pemiskinan) yang mengakibatkan kemiskinan, banyak terjadi dalam masyarakat terjadi dalam masyarakat di Negara berkembang seperti penggusuran dari kampong halaman, eksploitasi. Namun pemiskinan atas perempuan maupun laki yang disebabkan jenis kelamin merupakan salah satu bentuk ketidakadilan yang disebabkan gender. Sebagai contoh, banyak pekerja perempuan tersingkir dan menjadi miskin akibat dari program pembangunan seperti internsifikasi pertanian yang hanya memfokuskan petani laki-laki. Perempuan dipinggirkan dari berbagai jenis kegiatan pertanian dan industri yang lebih memerlukan keterampilan yang biasanya lebih banyak dimiliki laki-laki.

Selain itu perkembangan teknologi telah menyebabkan apa yang semula dikerjakan secara manual oleh perempuan diambil alih oleh mesin yang ummunya dikerjakan oleh tenaga laki-laki.

b. Subordinasi

Subordinasi pada dasarnya adalah keyakinan bahwa salah satu jenis kelamin dianggap lebih penting atau lebih utama dibanding jenis kelamin lainnya. Sudah sejak dahulu ada pandangan yang menempatkan kedudukan dan peran perempuan lebih rendah dari laki-laki. Banyak kasus dalam tradisi, tafsiran ajaran agama maupun dalam aturan birokrasi yang meletakan kaum perempuan sebagai subordinasi dari kaum laki-laki. Kenyataan memperlihatkan bahwa masih ada nilai-nilai masyarakat yang membatasi ruang gerak terutama perempuan dalam kehidupan. Sebagai contoh apabila seorang isteri yang hendak mengikuti tugas belajar, atau hendak berpergian ke luar negeri harus mendapat izin suami, tatapi kalau suami yang akan pergi tidak perlu izin dari isteri.

c. Pandangan stereotipe

Setereotipe dimaksud adalah citra baku tentang individu atau kelompok yang tidak sesuai dengan kenyataan empiris yang ada. Pelabelan negatif secara umum selalu melahirkan ketidakadilan. Salah satu stereotipe yang berkembang berdasarkan pengertian 
gender, yakni terjadi terhadap salah satu jenis kelamin, (perempuan), Hal ini mengakibatkan terjadinya diskriminasi dan berbagai ketidakadilan yang merugikan kaum perempuan. Misalnya pandangan terhadap perempuan yang tugas dan fungsinya hanya melaksanakan pekerjaan yang berkaitan dengan pekerjaan domistik atau kerumahtanggaan. Hal ini tidak hanya terjadi dalam lingkup rumah tangga tetapi juga terjadi di tempat kerja dan masyaraklat, bahkan di tingkat pemerintah dan negara.

Seorang laki-laki marah, ia dianggap tegas, tetapi bila perempuan marah atau tersinggung dianggap emosional dan tidak dapat menahan diri. Standar nilai terhadap perilaku perempuan dan laki-laki berbeda, namun standar nilai tersebut banyak menghakimi dan merugikan perempuan.

Label kaum perempuan sebagai "ibu rumah tangga" merugikan, jika hendak aktif dalam "kegiatan laki-laki" seperti berpolitik, bisnis atau birokrat. Sementara label laki-laki sebagai pencari nakah utama, (breadwinner) mengakibatkan apa saja yang dihasilkan oleh perempuan dianggap sebagai sambilan atau tambahan dan cenderung tidak diperhitungkan.

\section{d. Kekerasan}

Berbagai bentuk tidak kekerasan terhadap perempuan sebagai akibat perbedaan, muncul dalam bebagai bentuk. Kata kekerasan merupakan terjemahkan dari violence, artinya suatu serangan terhadap fisik maupun integritas mental psikologis seseorang. Oleh karena itu kekerasan tidak hanya menyangkut serangan fisik saja seperti perkosaan, pemukulan dan penyiksaan, tetapi juga yang bersifat non fisik, seperpti pelecehan seksual sehingga secara emosional terusik.

Pelaku kekerasan bermacam-macam, ada yang bersifat individu, baik di dalam rumah tangga sendiri maupun di tempat umum, ada juga di dalam masyarakat itu sendiri. Pelaku bisa saja 
suami/ayah, keponakan, sepupu, paman, mertua, anak laki-laki, tetangga, majikan.

e. Beban Ganda

Bentuk lain dari diskriminasi dan ketidak adilan gender adalah beban ganda yang harus dilakukan oleh salah satu jenis kalamin tertentu secara berlebihan. Dalam suatu rumah tangga pada umumnya beberapa jenis kegiatan dilakukan laki-laki, dan beberapa dilakukan oleh perempuan. Berbagai observasi, menunjukkan perempuan mengerjakan hampir $90 \%$ dari pekerjaan dalam rumah tangga. Sehingga bagi mereka yang bekerja, selain bekerja di tempat kerja juga masih harus mengerjakan pekerjaan rumah tangga. ${ }^{3}$

Proses pembangunan, kenyataannya perempuan sebagai sumber daya insani masih mendapat pembedan perlakuan, terutama bila bergerak dalam bidang publik. Dirasakan banyak ketimpangan, meskipun ada juga ketimpangan yang dialami kaum laki-laki di satu sisi.

\section{Perempuan dalam peran Domestik dan Publik}

Akhir-akhir ini banyak diperbincangkan tetang berbagai peran perempuan. Perempuan sebagai pemeran kodrat tradisional seakanakan tergeser karena modernisasi. Perempuan mulai meninggalkan rumah tangga untuk bekerja diluar rumah mengakibatkan perubahan fungsi dalam keluarga. Kejadian yang berskala mikro tersebut hendaknya dapat kaji lebih lanjut karena tidak semua perempuan memiliki potensi demikian. Banyak juga perempuan yang mampu berkarya diluar rumah tangga, tetapi tetap berperan sebagi ibu rumah tangga, kejadian seperti ini disebabkan oleh karena unsur sekelilingnya dan kedewasaan serta pola berpikirnya mampu mendukung, misalnya tingkat pendidikan, lingkungan pergaulan, dan hubungan interpersonal yang baik, sangat berperan dalam

\section{${ }^{3}$ Ibid}


mendukung kanca perempuan yang berorientasi menuju citacitanya. ${ }^{4}$ (Gusti,

Pengertian bahwa peranan perempuan mengandung anak, membuatnya berada pada posisi subordinat adalah suatu ide yang penting. Konsentrasi kaum peremuan dalam pekerjaan rumah tangga dan tersisihkannya mereka dari angkatan kerja telah merampas mereka dari sumber-sumber daya yang dapat digunakan dalam perjuangan untuk mendapatkan kesetaraan dengan kaum lakilaki.

Pudjiwati (1981) dalam penelitiannya tentang peranan perempuan di Jawa Barat, melakukan analisis pembagian kerja atas dasar alokasi waktu dari kegiatan yang dilakukan oleh perempuan baik di dalm maupun diluar rumah yang mengungkapkan bahwa pada umumnya waktu yang digunakan untuk kegiatan-kegiatan rumah tangga lebih lama atau padat ${ }^{5}$.

Di penelitian lain yang dilakukan Pudjiwati (1999) tentang peranan perempuan dalam perkembangan masyarakat Desa, membagi atas dua tipe peranan:

a. Pola Peran yang menggambarkan bahwa peran perempuan seluruhnya hanya dalam pekerjaan rumah tangga atau pekerjaan pemeliharaan kebutuhan hidup.

4 Su'adah. Sosiologi Keluarga.( Malang: Universitas Muhammadiyah Malang 2005).60

${ }^{5}$ Pudjiwati Sajogyo. Peranan Wanita dalam Keluarga, Rumah Tangga dan Masyarakat yang Lebih Luar di Pulau Jawa (Jakarta Universitas Indonesia 1981) 12 
b. Pola peranan dimana perempuan mempunya dua peranan yaitu peranan dalam rumah tangga dan mencari nafkah. ${ }^{6}$

Rasdiyana (1999) membagi peranan perempuan kedalam tiga bagian

a. peran kodrati yakni secara historis kultural peran perempuan yang dikaitkan dengan kerumah tanggaan yang didasarkan pada kodrat kewanitaan yang mengakar pada aspek biologis. Dilihat dari aspek budaya dan agama maka peran kodrati peran reproduksi.

b. Peran produktif (Peran ekonomi), yakni peran yang dapat dilakukan oleh laki-laki namun jika perempuan mampu melakukannya atas dasar kemauannnya sendiri sebagai pilihan berarti keduanya mempunyai peran yang sama.

c. Peran sosial (peran kemayrakatan) yakni peran yang multifungsi, maksudnya seorang ibu memiliki ilmuan atau politisi yang sukses. ${ }^{7}$

Parson (dalam Paloma 1994) mengenalkan bahwa masyarakat itu sebagai sistem yakni setiap sistem harus memiliki alokasi seperti alokasi peran misalnya istri berperan mengurus urusan domestik dan suami berperan mencari nafkah, alokasi fasilitas misalnya petani harus memiliki lahan dan seorang guru harus memiliki pendidikan dan alokasi imblan berupa materi atau amal. ${ }^{8}$

Menurut Hebeis dan Vitayala (dalam Sua'dah) peran perempuan dapat dilihat dari tiga presfektif dalam kaitannya dengan

${ }^{6}$ Pudjiwati Sajogyo, Peranan Wanita dalam Perkembangan Masyarakat Desa, (Jakarta, CV Rajawali 1999) 27 $1999) 13$

${ }^{7}$ Andi Rasdiyana, Gender dalam Presfektif Islam, (Makassar,

${ }^{8}$ Margaret Poloma . Sosiologi Kontemporer. ( Jakarta: Raja Grafindo Persada.1994) 
posisi sebagai manajer rumah tangga dan partisipasi pembangunan atau pekerja mencari nafkah

a. Peran tradisi peran Domestik (PD) yakni peran rumah tanggga

b. Peran Domestik (PD) dan Peran Publik (PP), yakni perempuan yang memiliki peran ganda

c. Peran Kontemporer atau peran Publik (PP). Perempuan yang memiliki peran ini biasanya di sebut dengan wanita karir atau wanita modern.atau wanita kontemporer. ${ }^{9}$

Selanjutnya Boserup 1970 (dalam Rabihatun: 1998) mengatakan bahwa peran perempuan sebagai penyumbang tenaga kerja di luar kegiatan rumah tangga ditentukan oleh kondisi masyarakat. ${ }^{10}$ Beberapa suku di Afrika hampir semua tugas berkaitan dengan produksi makanan diserahkan pada perempuan, demikian pula dalam sistem peladangan (Shifting Culvation) perempuan lebih lama bekerja dari pada laki-laki. Maka secara empiris dan analisis peran perempuan merupakan perpaduan peran antara didalam dan di luar rumah tangga dalam bentuk kombinasi -kombinasi yang disesuaikan dengan kondisi hidup perempuan itu sendiri

\section{Peran Perempuan Sebagai Agen Sosialisasi dalam Keluarga}

Berbicara tentang sosialisasi, maka tidak lepas dengan proses internalisasi. Sosialisasi merupakan agen yang memberikan suatu pencerahan berupa nilai, norma atau aturan-aturan dan budaya pada

${ }^{9}$ Hubeis A. Vitalaya S, Peran Sosial Ekonomi Kaum Wanita di Dua Area Pembangunan Sulawesi, (Bogor , Samtego Gunawasangka 1987). $45-50$

${ }^{10}$ Rabihatun, Idris, 1998. Hubungan Antara Tingkat Pendidikan dan Pemanfaatan Angkatan Kerja Wanita di Desa di Sulawesi Selatan (Kasus Tiga Desa di Kab. Sinjai). ( Ujung Pandang: Pascasarjana UNHAS.1990) 52 
pihak yang disosialisasi dalam artian anak. Pihak yang disosialisasi juga melakukan proses kognitif (berpikir/mencerna) terhadap apa yang diterima dari pihak yang mensosialisasi. Proses inilah yang disebut sebagai proses internalisasi.

Ada dua tahap dalam proses internalisasi yakni tahap pertama individu melakukan interpertasi atau penafsiran terhadap sesuatu yang disampaikan dari pihak yang mensosialisasi. Dan kedua meresapi dan mengorganisir semua makna yang diinterpertasi kemudian diserap dalam bathin dan pikiran dan hal inilah yang menghasilkan kepribadian.

Zanden (dalam Ihromi 1987) berpendapat bahwa sosialisasi adalah proses seorang individu untuk interaksi sosial dengan sesamanya untuk mengenal cara-cara berpikir, berperasaan dan berperilaku sehingga dapat berperan serta secara efektif dalam masyarakat. Hal ini didukung pendapat Goslin mengatakan bahwa sosialiasasi merupakan proses belajar yang dialami seseorang untuk memperoleh pengetahuan, keterampilan, nilai-nilai dan norma agar ia dapat berpartisipasi sebagai anggota dalam kelompok masyarakat ${ }^{11}$

Sosialisasi adalah suatu proses sosial yang dilakukan oleh seseorang dalam menghayati norma-norma kelompok tempat ia hidup sehingga menjadi bagian dari kelompoknya. Soe'oed (1999) mendefinisikan sosialisai sebagai suatu interaksi sosial yaitu interaksi sesama a nggota masyarakat yang mengenal cara-cara berpikir, berperasaan dan berperilaku, sehingga dapat berperan secara efektif di dalam masyarakat, dalam hal ini yang dipelajari dalam sosialisasi

${ }^{11}$ Ihromi, Suryochondro, Amal, Lestari dan Sulaeman., Keluarga Dimana Ibu Berperan Ganda dan Berperan Tunggal.(Jakarta: Laporan Penelitian Lembaga Penelitian Universitas Indonesia: 1987) 150 
adalah nilai, norma dan simbol. ${ }^{12}$ Selanjutnya Goode memberikan definisi sosialisasi sebagai sebuah proses yang harus dilalui manusia untuk memperoleh nilai-nilai dan pengetahun mengenai kelompoknya dan belajar tentang peran sosialnya yang cocok dengan kedudukannya. $^{13}$

Dilihat dari peran perempuan sebagai agen Sosialisasi adalah merupakan faktor penentu berhasil tidaknya terhadap apa yang disampaikan pada yang disosialisasi oleh karena agen sosialisasi adalah pihak-pihak yang melaksanakan atau melakukan sosialisasi. Agen sosialisasi yang dimaksud menurut Fuller dan Jacobs adalah keluarga, kelompok bermain, media massa dan lembaga pendidikan sekolah. ${ }^{14}$

Ada tiga pandangan para pakar sosiologi yang membicarakan tetang peran yakni:

a. Pandangan George Herbert Mead

Mead (1934), berpandangan bahwa sosialisasi yang dimulai seseorang dapat dibedakan melalui empat tahap-tahap sebagai berikut:

Tahapan pertama adalah tahap persiapan (preparatory state), ini dialami sejak manusia dilahirkan, saat seorang anak mempersiapkan diri untuk mengenal dunia sosial, termasuk untuk memperoleh pemahaman tentang dirinya. ditahap ini juga anak-anak mulai melakukan kegiatan meniru meski tidak sempurna, contoh kata 1999), 23

${ }^{12}$ Soe'oed,. Proses sosialisasi. (Jakarta: Yayasan Obor Indonesia.

13 J.William.Goode, Sosiologi Keluarga. J(akarta: Bumi Aksara 2004), 12

${ }^{14}$ Jonh Fuller, Scott dan Jerry Jacobs. Socialization. Dalam Jack D. Dauglas (ed), Introdution to Sociology: Situations and Structures.( New York: The Free Press 1973) 43. 
makan yang diajarkan oleh ibu kepada anaknya yang masih balita diucapkan "mam". Makna kata tersebut juga belum dipahamitepat oleh anak, tetapi lama kelamaan anak memahami secara tepat makna kata tersebut dengan kenyataan yang dialaminya. ${ }^{15}$

Proses sosialisasi adalah berlangsung pada tahap ini menurut Ihromi, belum nyata (laten). Pengenalan anak terhadap diri sendiri tidak jelas dan anak belum merupakan kesatuan individu yang berdiri sendiri dan yang dapat melakukan interaksi dengan temannya. Jadi anak dalam tahap ini dianggap sebagai bagian dari ibu dan anak masih merupakan satu kesatuan yang disebut two persons system. ${ }^{16}$

Tahapan kedua ialah tahap meniru (play stage), hal ini ditandai dengan semakin sempurnanya seorang anak meniru peran-peran yang dilakukan oleh orang-orang dewasa. Pada tahap ini mulai terbentuk kesadaran tentang nama dirinya dan nama orang tuanya, kakak dan sebagainya. Anak mulai menyadari tentang apa yang dilakukan seorang ibu dan apa yang diharapkan oleh ibu dari anak. Dengan kata lain kemampuan untuk menempatkan diri (adaptasi) pada posisi orang lain juga mulai terbentuk pada tahap ini.

Kesadaran bahwa dunia sosial manusia berisikan banyak orang juga mulai terbentuk. Sebahagian dari orang tersebut merupakan orang-orang yang dianggap penting bagi pembentukan diri yakni dari mana anak menyerap norma, nilai, dan budaya. Bagi seorang anak orang-orang ini di sebut orang-orang yang amat berarti (significant other). Konsep ini menggambarkan bahwa konsep diri anak di temukan pada wilayah permainan yakni pada awal individu meniru

${ }^{15}$ George Herbert Mead, 1934. Mind, self and society, (edited and with an introduction by Charles.W.Morris, Chicago: University of Chicago Press 1934), 90.

${ }^{16}$ Ihromi,T.O. Bunga Rampai Sosiologi Keluarga, ( Jakarta: Yayasan Obor Indonesia, 1999 ) 12 
peran-peran orang tua yang ada disekitarnaya misalnya ketika anak bermain dengan teman sebayanya mereka berperan sebagai ibu, atau sebagai bapak bahkan berperan sebagai dokter.

Tahap ketiga adalah tahap siap bertindak (game stage), proses sosialisasi pada tahap ini disebut tahap pencapaian tujuan yakni tingkah laku anak tidak lagi hanya menyesuaikan diri, tetapi lebih terarah untuk maksud dan tujuan tertentu. Ia cenderung mengulangi tingkah laku tertentu untuk mendapatkan penghargaan dari orang tua dan tingkah laku yang menimbulkan reaksi negatif dari orang tua berusaha di hindari.

Peniruan pada tahap ini sudah mulai berkurang dan digantikan oleh peran yang dimainkan sendiri dengan penuh kesadaran. Kemampuanya menepatkan diri pada posisi orang lain pun meningkat, sehingga memungkinkan adanya kemampuan bermain secara bersamasama. Dia mulai menyadari adanya tuntutan untuk membela keluarga dan bekerja sama dengan teman-temannya. Pada tahap ini lawan berinteraksi semakin banyak dan hubungan dengan teman sebaya di luar rumah. Peraturan-peraturan yang berlaku dalam keluarganya secara bertahap sudah mulai difahami. Bersama dengan itu anak mulai menyadari bahwa ada norma-norma tertentu yang berlaku dalam keluarganya.

Konsep ini dipahami bahwa pada tahap ini anak-anak bukan saja meniru peran orang lain, tetapi sudah mulai memaknai peranperan yang dimainkan. Dia tidak hanya memahami dirinya tetapi juga sudah memahami peran orang lain. Misalnya ketika anak bermain bola dia sudah memahami peran teman-temanya sebagai penjaga gawang, penyerang dan lain-lain.

Tahap keempat yakni tahap penerimaan norma kolektif (generalized stage), nampak bahwa tingkah laku anak pada tahap ini tidak lagi hanya sekedar penyesuaian diri (adaptasi) ataupun untuk mendapatkan penghargaan dari orang tuanya (tujuan), namun sudah menjadi bagian dari dirinya sendiri yang ingin dilakukannya 
(terintegrasi dalam dirinya sendiri). Norma dan nilai yang ditanamkan oleh orang tuanya sudah menjadi diri anak atau kata hati (conscience) dari anak dan bukan lagi berada di luar diri anak. ${ }^{17}$

Di tahap ini seseorang telah dianggap dewasa. Dia sudah dapat menempatkan dirinya pada posisi masyarakat secara luas. Dengan kata lain, ia dapat bertenggang rasa tidak hanya dengan orang-orang yang berinteraksi dengannya tapi juga dengan masyarakat luas. Manusia dewasa menyadari pentingnya peraturan, kemampuan kerja sama bahkan dengan orang lain yang tidak dikenalnya secara mantap. Manusia dengan perkembangan diri pada tahap ini telah menjadi warga masyarakat dalam arti sepenuhnya. ${ }^{18}$

b. Pandangan Charles Horton Colley

Colley (1964) menekankan pada peranan interaksi dalam teorinya. Menurutnya bahwa "konsep diri (self concept) seseorang berkembang melalui peran interaksinya dengan orang lain, yang kemudian di sebut sebagai teori looking-glass of self (cermin diri) “19 yang terbentuk melalui tiga tahap yakni:

Pertama, presepsi pandangan orang lain terhadap dirinya. Yakni anak merasa dirinya sebagai anak yang paling pintar atau hebat karena sang anak memiliki prestasi di kelas dan sering menang diberbagai lomba.

Kedua, presepsi penilaian orang terhadap dirinya. Bahwa ketika anak adalah anak yang hebat, anak membayangkan pandangan orang lain terhadapnya. Ia berpendapat bahwa orang lain selalu

${ }^{17}$ Ibid Jhonson Doyle Paul, Teori Sosiologi Klasik dan Modern. (diterjemahkan oleh Robert M.Z Lawang, Jilid II, Jakarta: Gramedia 1986). 6

${ }^{19}$ Horton Cooley, . Human Nature and the Social Order. (New York: Schocken Books. 1964) 77 
memuji dirinya dan selalu percaya pada tindakannya. Persaan ini bisa muncul dari perlakuan orang terhadap dirinya. Misalnya nya selalu mengikut sertakan dirinya dalam berbagai lomba atau orang tuanya selalu memamerkannya kepada orang lain. Tetapi perlu dipahami bahwa penilaian ini belum tentu benar. Sang anak munkin merasa dirinya hebat pada hal jika dibandingkan dengan orang lain ia tidak ada apa-apanya. Perasaan hebat ini bisa jadi menurun jika sang anak memperoleh informasi dari orang lain bahwa ada anak yang lebih hebat dari dia.

Ketiga adalah perasaan (respon) individu terhadap perasaan orang lain. Adanya penilaian bahwa sang anak adalah anak hebat. Maka timbul perasaan bangga dan penuh percaya diri. ${ }^{20}$

Konsep tersebut dipahamibahwa untuk mengetahui diri sendiri, maka fahami pandangan atau penilaian orang lain. Contoh lain dari gambaran di atas ketika seorang mahasiswa mendapatkan nialai $\mathrm{E}$ dalam empat mata kuliah maka pandangan dosen dia adalah malas, dan penilaiannya bodoh dan mahasiswa merasa dirinya malas dan bodoh yang pada akhirnya akan merasa tidak nyaman ketika bertemu dengan dosennya.

Tahapan-tahapan di atas berkaitan erat dengan teori labeling, dimana seseorang akan berusaha memainkan peran sosial sesuai dengan sesuai dengan penilaian orang terhadapnya. Jika seorarng dicap sebagai orang lemah, maka ada kemungkinan ia akan memainkan peran sebagai " sebagai orang lemahl” sesuai dengan penilaian orang terhadapnya, walaupun penilaian itu belum tentu kebanarannnya.

Proses sosialisasi akan membuat orang belajar tentang nilai, norma, bahasa, simbol, .keterampilan dan sebagainya untuk dapat diterima dalam masyarakat dimana orang itu berada. Oleh karena itu 2004). 35

${ }^{20}$ Gerungan, Psikologi Sosial. ( Bandung: Refika Aditama, 
agar dapat diterima dalam masyarakat diperlukan kemampuan untuk menilai secara obyektif perilaku sendiri dari sudut pandang orang lain. Selanjutnya kemampuan tersebut yang dimiliki oleh seseorang berarti individu tersebut sudah memiliki self (diri). Self terbentuk dan berkembang melalui proses sosialisasi, dengan cara berinteraksi dengan orang lain. Orang yang memiliki self adalah orang yang mampu mereflesikan atau memberlakukan dirinya sebagai objek dan subjek sekaligus.

c. Pandangan Herbert Blumer

Blumer (1969) berpandangan bahwa konsep diri didapatkan dalam tiga tahap yakni: (1) setiap individu bertidak berdasarkan makna-makna yang di tangkap atau dipahamiterhadap tindakan, (2) makna yang diperoleh berdasarkan hasil interaksi dengan orang lain dan (3) ada pemahaman bersama atau kerja sama didasarkan atas pemahaman bersama, artinya di dalam memahami individu ada kesamaan presepsi atau penilaian dari dua orang atau lebih, sehingga kesanya tidak obyektif dalam penilaian diri individu ${ }^{21}$.

Teori tersebut di atas mempunyai kemiripan dengan teori Emile Durkheim (1858-1917), dalam Gerungan melihat gejala-gejala sosial. Menurut Durkheim bahwa yang mendasari gejala-gejala sosial itu adalah kesadaran kolektif dan bukan kesadaran individual .22 .

Durkheim melihat bahwa masyarakat terdiri atas kelompokkelompok manusia yang hidup secara kolektif dengan pengertian dan tanggapan yang kolektif, dan hanya kehidupan kolektif ini yang dapat menerangkan gejala-gejala sosial maupun gejala-gejala kemasyarakatan. menurutnya bahwa masyarakat adalah sistem yang mengikat kehidupan orang-orang dan merupakan lingkungan (milieu)

${ }^{21}$ Herbert Blumer, Symbolic Interactionism, Perspective and Method. ( Englewood Cliffs, N.j: Prentice-Hall, 1969) 103.

${ }^{22}$ Gerungan Psikologi Sosial , 200459 
yang menguasai segala kehidupan. Ikatan masyarakat ini terdapat individu terutama ditentukan oleh pambagian tugas pekerjaan dalam masyarakat, dalam artian setiap individu ada peranan yang harus dimainkan dalam kelompok maupun dalam masyarakat ${ }^{23}$ Norma dan nilai-nilai sosial yang pada mulanya tidak terdapat pada diri individu itu sendiri lambat laun diberikan bahwa kerap kali dipaksakan oleh masyarakat terhadap individu itu. Nyata bahwa pada pendapat Durkheim mengenai saling hubungan antara individu dan kelompok sangat mengutam akan peran kelompok.

\section{Implementasi Kesetaraan dan Keadilan Gender dalam Keluarga}

Implementai kesetaraan gender berarti memperaktekan hasil kegiatan atau pelatihan mengenai kesamaan kondisi bagi laki-laki dan perempuan untuk memperoleh kesempatan serta hak-hak sebagai manusia, agar mampu berperan dan berpartisipasi dalam kegiatan politik, hukum, ekonomi, sosial budaya, pendidikan dan pertahanan dan keamanan nasional (hankamnas), keluarga serta kesamaan dalam menikmati hasil pembangunan tersebut. Kesetaraan gender juga meliputi penghapusan diskriminasi dan ketidak adilan struktural, baik terhadap laki-laki maupun perempuan.

Pemahaman ini pada awalnya mayarakat peremempuan belum memahami sesungguhnya pengertian tentang keadilah gender meskipun namun aplikasinya dalam keluarga sudah terwujud, namun dengan adanya kerja dalam keluarga dalam memberdayakan perempuan ataupun dari masyarakat telah memahami makna tentang gender.

Di fahami bahwa keadilan gender adalah suatu proses dan perlakuan adil terhadap perempuan dan laki-laki. Dengan keadilan

\section{${ }^{23} \underline{\mathrm{Ibid}}$}


gender berarti tidak ada pembekuan peran, beban ganda, subordinasi, marginalisasi dan kekerasan terhadap perempuan maupun laki-laki. Maka pemberian kesempatan untuk menempuh pendidikan sampai ke jenjang pendidikan Perguruan Tinggi pada masyarakat merupakan salah satu bukti bahwa tidak terjadi lagi adanya subordinatkan atau melakukan pembekuan peran perempuan terkait pendidikan.

Berdasarkan uraian di atas dapat di fahami bahwa ciri-ciri implementasi perwujudan ketaraan gender dan anak telah di miliki dalam keluarga. Terwujudnya kesetaran dan keadilan gender dalam keluarga ini ditandai dengan tidak adanya diskriminasi antara perempuan dan laki-laki, dan dengan demikian mereka memiliki akses, kesempatan berpartisipasi, dan kontrol atas pembangunan serta memperoleh manfaat yang setara dan adil dari pembangunan.

Dilihat dari fungsi keluarga maka dalam keluarga pun setiap individu memiliki fungsi yakni ibu berfugsi untuk kenjaga ketuhan keluarga dengan tanggungjabnya sebagai ibu rumah tanggga, ayah berfunsi sebagai kepala rumah tangga yang harus memenuhi kebutuhan keluarga dan menjalankan kewajibanya untuk kegiatan pendidikan yang merupakan hal pokok dalam bangunan keluarga, karena itu fungsi dari keluarga inti tidaklah hanya merupakan kesatuan biologis, tetapi juga merupakan bagian dari hidup bermasyarakat. Disini keluarga bukan hanya bertugas memelihara anak, tetapi berfungsi untuk membentuk ide dan sikap sosial, sehinga keluarga itu mempunyai kewajiban untuk meletakkan dasar-dasar pendidikan, rasa keagamaan, kemauan, kesukaan, keindahan, kecakapan berekonomi dan pengetahuan perniagaan.

Berdasarka uraian di atas maka dapat di simpulkan bahwa pemenuhan kebutuhan biologis, wadah emosional atau perasaan, pendidikan sosialisasi, ekonomi dan pemuasan sosial merupakan hal yang penting dalam mewujudkan fungsi keluarga dalam tiga bentuk yakni: 
a. Mengurus keperluan materil anak. Ini merupakan tugas pertama dari orang tua harus memenuhi kebutuhan hidup, tempat perlindungan dan pakaian kepada anak-anak;

b. Menciptakan suatu "home" bagi anak-anak. "Home" disini berarti, bahwa di dalam keluarga anak-anak dapat berkembang dengan subur, merasakan kemesraan, kasih sayang keramahtamaan, merasa aman, terlindungi dan sebagainya;

c. Tugas pendidikan. Merupakan tugas terpenting dari orang tua terhadap anak-anaknya.

Keluarga merupakan komunitas primer yang terpenting dalam masyarakat. Komunitas primer artinya suatu kelompok dengan kedekatan antara anggota-anggotanya yang sangat erat. Sehihingga secara historis keluarga terbentuk dari satuan yang merupakan organisasi terbatas dan mempunyai ukuran yang minimum, terutama pada pihak-pihak yang awalnya mengadakan suatu ikatan. Ia merupakan bagian dari masyarakat yang berintegrasi dan mempunyai peran dalam suatu proses organisasi kemasyarakatan.

Di fahami bahwa dalam keluarga terdiri atas ayah, ibu dan anak yang menurut pakar sosiologi di sebut sebagai grup sosial (dari kata sosial group=kelompok sosial) yang dicirikan oleh tempat tinggal bersama, kerja sama dari dua jenis kelamin (perempuan dan laki-laki), paling kurang dua darinya atas dasar pernikahan dan satu atau lebih anak yang tinggal bersama mereka yang tentunya masingmasing keluarga memiliki kebijakan atau aturan-aturan yang berbeda-beda tergantung konstruk budaya dan kondisi lingkungan.

Berdasarkan hasil wawancara tersebut penulis melihat keluarga merupakan satu-satunya lembaga sosial yang diberi tanggung jawab untuk mengubah organism biologi menjadi manusia, sehingga dapat memberikan sebuah persamaan, bahwa untuk mengubah organism biologis menjadi organism sosiologis 
membutuhkan keluarga sebagai agen tempat mengenal dan mempelajari prototype peran tingkah laku yang dikehendaki dan modus orientasi penyesuaian diri dengan yang dikehendaki dan modus orientasi penyesuaian diri dengan lingkungan sosialnya.

Pelaku utama dalam dalam prosese sosialisasi anak adalah tentung ibu (perempuan) yang merupakan sosok paling dekat dalam memaikan peran atau hubungan yang dirasakan anak dengan kelurganya, yang tentunya membuat keluarga menjadi satu-satunya institusi sosial yang relative permanen dalam menjalankan fungsi sosialnya. Hal ini dimungkinkan karena keluarga dibentuk dari ikatan emosional (dorongan yang paling kuat dari sifat organis manusia untuk saling memilih satu dengan yang lainnya) antara anggotanya sangat di tentukan oleh perempuan .

Di lihat dari peran perempuan dalam keluraga yang sangat kompleks maka tentunya juga akan membutuhkan skill atau keterampilan yang memadai bagi perempuan dalam mengembangkan dirinya melalui beberapa pelatihan seperti pelatihan pemberdayaan perempuan baik dalam bentuk pemberdayaan ekonomi maupun dalam bentuk keagamaan.

\section{PENUTUP}

Berdasarkan Uraian di atas dapat diambil kesimpulan:

1. Keseteraan dan keadilan gender bagi perempuan penting di lakukan dalam keluarga sehingga dapat wawasan perempuan untuk memperoleh kesempatan serta hak-haknya sebagai manusia, sehingga mampu berperan dan berpartisipasi dalam kegiatan politik, hukum, ekonomi, sosial budaya, pendidikan dan pertahanan dan keamanan nasional (hankamnas), serta kesamaan dalam menikmati hasil pembangunan. 
2. Implementasi kesetaraan dan keadilan gender dalam keluarga adalah berfungsinya tatanan keluarga yang baik sebagai prasyarat mutlak bagi kelangsungan suatu generasi yang baru memperoleh nilai-nilai dan norma-norma yang sesuai dengan harapan masyarakat, terwujudnya sikap saling mengerti tentang peran masing-masing dalam keluarga yang ditandai dengan tidak adanya diskriminasi antara perempuan dan laki-laki, dan dengan demikian mereka memiliki akses, kesempatan berpartisipasi, dan kontrol atas pembangunan serta memperoleh manfaat yang setara dan adil dalam pembengunan di segala sektor.

\section{DAFTAR PUSTAKA}

Achmad, Muthali'in, Bias Gender dalam Pendidikan, Surakarta, Muhammadiyah University Press, 2001

Blumer, Herbert. . Symbolic Interactionism, Perspective and Method. Englewood Cliffs, N.j: Prentice-Hall, 1969

Colley, Horton , Human Nature and the Social Order. New York: Schocken Books. 1964

Gerungan, Psikologi Sosial. Bandung: Refika Aditama, 2004

George Herbert Mead, 1934. Mind, self and society, edited and with an introduction by Charles.W.Morris, Chicago: University of Chicago Press 1934.

Idris, Rabihatun. 1998. Hubungan Antara Tingkat Pendidikan dan Pemanfaatan Angkatan Kerja Wanita di Desa di Sulawesi Selatan (Kasus Tiga Desa di Kab. Sinjai). Ujung Pandang: Pascasarjana UNHAS.1990 
Ihromi, Suryochondro, Amal, Lestari dan Sulaeman., Keluarga Dimana Ibu Berperan Ganda dan Berperan Tunggal. Jakarta: Laporan Penelitian Lembaga Penelitian Universitas Indonesia :1987

Ihromi,T.O. Bunga Rampai Sosiologi Keluarga, Jakarta: Yayasan Obor Indonesia 1999

J.William.Goode, Sosiologi Keluarga. Jakarta: Bumi Aksara 2004

Jonh Fuller, Scott dan Jerry Jacobs. Socialization. Dalam Jack D. Dauglas (ed), Introdution to Sociology: Situations and Structures. New York: The Free Press 1973.

Paul Doyle Jhonson, Teori Sosiologi Klasik dan Modern. diterjemahkan oleh Robert M.Z Lawang, Jilid II, Jakarta: Gramedia 1986

Poloma .M, Margaret. Sosiologi Kontemporer. Jakarta: Raja Grafindo Persada.1994

Rasdiyana, Andi , Gender dalam Presfektif Islam, Makassar, 1999

Sajogyo, Pudjiwati, Peranan Wanita dalam Keluarga, Rumah Tangga dan Masyarakat yang Lebih Luar di Pulau Jawa, Jakarta Universitas Indonesia 1981

Sajogyo, Pudjiwati, Peranan Wanita dalam Perkembangan Masyarakat Desa, Jakarta, CV Rajawali 1999

Su'adah. Sosiologi Keluarga., Malang: Universitas Muhammadiyah Malang 2005

Soe'oed,. Proses sosialisasi. Jakarta: Yayasan Obor Indonesia. 1999

Vitalaya, S, Hubeis A., Peran Sosial Ekonomi Kaum Wanita di Dua Area Pembangunan Sulawesi. Bogor, Samtego Gunawasangka 1987 